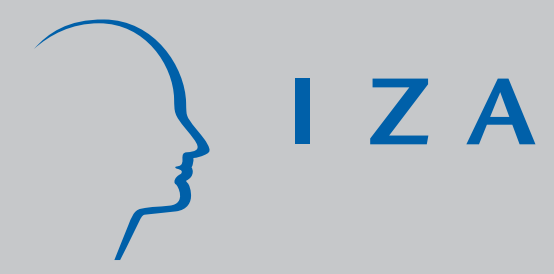

IZA DP No. 1516

Regionalism in West Africa:

Do Polar Countries Reap the Benefits?

A Role for Migration

Adama Konseiga

March 2005 


\title{
Regionalism in West Africa: Do Polar Countries Reap the Benefits? A Role for Migration
}

\author{
Adama Konseiga \\ Center for Development Research (ZEF)
}

and IZA Bonn

Discussion Paper No. 1516

March 2005

IZA

P.O. Box 7240

53072 Bonn

Germany

Phone: +49-228-3894-0

Fax: +49-228-3894-180

Email: iza@iza.org

Any opinions expressed here are those of the author(s) and not those of the institute. Research disseminated by IZA may include views on policy, but the institute itself takes no institutional policy positions.

The Institute for the Study of Labor (IZA) in Bonn is a local and virtual international research center and a place of communication between science, politics and business. IZA is an independent nonprofit company supported by Deutsche Post World Net. The center is associated with the University of Bonn and offers a stimulating research environment through its research networks, research support, and visitors and doctoral programs. IZA engages in (i) original and internationally competitive research in all fields of labor economics, (ii) development of policy concepts, and (iii) dissemination of research results and concepts to the interested public.

IZA Discussion Papers often represent preliminary work and are circulated to encourage discussion. Citation of such a paper should account for its provisional character. A revised version may be available directly from the author. 


\section{ABSTRACT \\ Regionalism in West Africa: Do Polar Countries Reap the Benefits? A Role for Migration*}

In the present globalization era an increasing attention is paid to the ambiguous relationship between international migration, brain drain, and economic growth, but few papers analyzed the growth impact of skilled migration. The paper filled the research gap by building the first dataset on brain drain from seven countries of the western African Union (WAEMU) and highlighted the size of the brain loss toward Côte d'Ivoire and France. Burkina Faso shows a more severe brain drain to Cote d'Ivoire compare to other similar sahelian countries whereas the reverse holds when considering the destination France. The subsequent empirical strategy consists in comparing the growth performance of an economy without migration to the counterpart economy. The regional growth convergence analysis shows higher convergence rate once the brain circulation is accounted for. However, the effect of brain gain holds only for countries with migration outside WAEMU toward an industrialized country (France) and failed when migration, as is the case for Burkina Faso, flows into Cote d'Ivoire the polar economy of the Union. Therefore, migration can be used as a powerful force working toward income convergence between capital-rich and capital-poor countries.

JEL Classification: E13, F22, J24, C230, O15, C82

Keywords: economic growth, brain drain, human capital formation, measurement error, panel estimation

Adama Konseiga

43 Rue du Docteur Bauer

93400 Saint Ouen

France

Email: akonseiga@yahoo.com

\footnotetext{
* The views and conclusions expressed in this paper are those of the author. They are neither the views of the Center for Development Research (ZEF), nor those of its collaborating partner the Center for International Development Studies and Research (CERDI). The author is grateful for comments and suggestions provided by Jean-Louis Combes, Jean-Louis Arcand, Susanna Wolf, Béatrice d'Hombres, and the Macroeconomic and Trade Research Group at ZEF. He also acknowledges the technical cooperation during the data collection from Philippe Bocquier and Xavier Thierry. However, the usual disclaimer applies.
} 


\section{$1 \quad$ Introduction}

For the past decades trade and financial globalization have been the focus of multilateral negotiations with the need to expand and strengthen the multilateral trade system and to prevent the recurrence of disruptive financial crises in emerging markets. However, the international labor market remains completely absent in the agenda of the international economic system. In the most recent decade, migration policies have instead taken a new turn with migration flows viewed as a challenge for the social stability and economic growth for both the receiving and the sending countries.

On the one hand, in response to the growing shortages of skilled labor, immigration policies in industrialized receiving countries have increasingly been geared to favor the entry of skilled workers, while continuing to penalize unskilled flows. The highly talented workers are essentially becoming more globally mobile as goods, services and capital has become more globally mobile over time. Under this brain circulation perspective, the international mobility of skilled workers can generate global benefits by improving knowledge flows and satisfying the demand for high-skilled workers where the demand is strongest.

On the other hand, international migration continues to account for an important part of poor countries' livelihoods. Remittances alone represent each year 100 billion of US dollar, which corresponds to more than twice the total public aid to Development in $2000^{1}$. While in the nineteenth century migration flows played a key role in fostering income convergence between Europe and the United States, a similar outcome may now be expected at national and regional levels where most of the migration is taking place in the present globalization context.

It is the aim of the present paper to study the convergence impact of migration because an important achievement of the regional arrangements in West Africa has been to promote the free movement of persons. This policy results in important international migration flows in West African region. Considering the period 1960-90, nearly 12 percent of the total West African population (excluding Nigeria) no more resides in their

Restriction of the labor migration is increasingly gaining recognition as a direct impediment to trade, particularly in services. 
homeland. Intra-African migration flows appear to be the best argument for regional integration.

Yet, the focus of the New Economics of Migration (NEM) is the determinants of migration and the characteristics of migrants at micro levels. The consequences of migration in departing and arriving country have not been so far fully studied.

The basic neoclassical macroeconomic model of growth assumes that population and labor force grow together at the exogenous rate $n$. This assumption holds only in the context of a closed economy. When the economies can trade, under perfect labor or capital mobility, convergence ${ }^{2}$ of per capita outputs and wages is immediate, therefore the neoclassical model cannot explain the kind of slow convergence documented in the literature. If capital markets are perfect and there are no transaction costs, rates of return are equalized and if capital can be moved without costs from one economy to the other or from one firm to the other, the marginal product will be equal to the interest rate and so equal across the different economies. Blanchard (1989) suggests that human migration may be responsible for restoring the kind of convergence observable in empirical studies.

The present paper examines the possibility of immigration and emigration in response to economic opportunities within the West African Economic and Monetary Union $\left(\mathrm{WAEMU}^{3}\right)$ regional group, for given mortality and fertility. Therefore, the migration of persons is the main mechanism for change in an economy's population and labor supply. However, unlike natural population growth, gains in population for the destination economy may represent corresponding losses for the source economy (labor force and possibly human capital), and this brings into the debate the brain drain issues. I examine the total macroeconomic effects of labor mobility inside WAEMU where Côte d'Ivoire the polar economy (25 percent of all sub-Saharan African regional exports) represents the main attraction for migrants from landlocked countries (e.g. Burkina Faso with less than 0.9 percent of sub-Saharan African regional exports). While there is a consensus on the gains from migration to the home country accrue in the form of

2 Convergence is understood here as the tendency of poor economies to grow faster than rich ones. However, this is conditional when each economy converges to its own steady state values with monotonically diminishing growth rates.

3 The West African Economic and Monetary Union (WAEMU or UEMOA the French acronym) comprises eight countries: Benin, Burkina Faso, Côte d'Ivoire, Guinea Bissau, Mali, Niger, Senegal and Togo. 
migrants' remittances, creation of business and trade networks ("Diaspora effects") and migrants' return home with amplified skills acquired abroad, the net benefits rely on how extensive is the brain drain. The latter is understood as the estimates of immigrants in the host country by educational attainment as a fraction of the individuals in the laborexporting country with the same level of educational attainment.

First, the sections 2 and 3 respectively review the conventional brain drain and the new brain gain approaches. In section 4, I present the dataset built for the subsequent empirical analysis and then proceed with the econometrics of growth convergence. The empirical strategy consists in comparing the performance of an economy without migration to the counterpart economy. Following this strategy, I consider Burkina Faso that represents the most important sending country to Côte d'Ivoire relatively to Mali and the other WAEMU countries. Simultaneously I consider the case where the migration destination is France, which allows analyzing the reverse scenario where Burkina Faso has fewer migrants relatively to the other WAEMU countries. The findings support that there are different forces in play that make migration a force for both divergence and convergence depending on the parameters and the destination choice.

\section{The receiving country and the conventional brain drain}

I use the neoclassical growth model ${ }^{4}$ as a framework to examine whether migration plays an important role in the process of regional convergence.

In the closed neoclassical economy, the per capita growth rate tends to be inversely related to the starting level of output or income per person. This conducts to the result of convergence which implies that the growth rate of an economy is a decreasing function of the distance between its initial conditions and its own steady state.

The dynamics of the Solow model is entirely described by the path of capitallabor ratio, since population grows exogenously, capital depreciates at a fixed rate, and gross investment is proportional to output. Nerlove (2002) uses a partial adjustment model approximation to write the rate of convergence to equilibrium which can be estimated as:

4 Other justifications of the use of the Solow framework in empirical analysis are given in Arcand and d'Hombres (2002). Despite the popularity of endogenous growth theories as theoretical constructs within which the determinants of growth can be understood, it is difficult to test them structurally. 
$\log y=\frac{\alpha(1-\gamma)}{1-\alpha}[\log s-\log (n+\delta)]+\frac{1-\gamma}{1-\alpha} \log A+\gamma \log y_{t-1}$

where $\delta$ is the rate of depreciation, and $n$ is the growth rate of Labor. $\alpha$ and $A$ are the parameters of the Cobb-Douglas production function and $s$ the saving rate.

Clearly, the extent of convergence is conditional on s, n, and the time path of A with the speed of convergence $\beta$ toward the steady state inversely proportional to the coefficient of the initial output $\gamma$. This structural estimating equation is easily expanded to include the human capital in the same way as it is done with the physical capital, leading to the augmented Solow model. Therefore in empirical literature, the included regressors are usually the initial level of GDP per capita, the log of the investment ratio minus the population growth rate, and the stock of human capital. Time specific dummies can be also included when using the within procedure. In fact including human capital in an empirical implementation of the Solow growth model reduces the point estimate of the coefficient associated with physical capital, held to be much too high in light of the mean value of labor's share in GDP across countries and across time periods (Arcand and d'Hombres 2002).

Barro and Sala-i-Martin (1992) derives a simplified expression of the convergence based on equation (1):

$\beta=(1-\alpha)(x+n+\delta)$

that is, the speed of convergence is an increasing function of the exogenous productivity growth rates, population growth and depreciation and a decreasing function of the capital share $\alpha^{5}$.

However, the core Solow model cannot be applied to Free Trade Area (FTA) where inputs of production can move across economies: people can migrate, physical capital can be easily transported, and financial markets allow for borrowing and lending across countries. The neoclassical economic theory suggests that differences in income and output per capita between countries tend to diminish over time, as factors of production relocate in response to relative cost/price advantages. Migration which is induced by income differentials will, other things being equal, play a catch up role and serve to

5 In a simple neoclassical setting, the speed of convergence is independent of utility parameters (and therefore independent of the saving rate). 
reduce those differentials as the relative labor scarcity which started the process is mitigated (Kanbur and Rapoport 2003). This convergence is typically viewed to carry important benefits, including a more efficient use of resources and higher levels of output for a union as a whole (Kaufman, Swagel, and Dunaway 2003). Since the main concern of the current paper is to investigate the convergence effect of labor mobility within trade blocks, I build on and adapt the basic Solow framework as previously presented. ${ }^{6}$

Suppose that the model allows only the mobility of persons but the economy is closed with respect to foreign goods and assets i.e. capital immobility. This assumption allows extracting the effects of migration on the growth process (Barro and Sala-i-Martin 1995).

$M(t)$ is the flow of migrants into the destination or polar economy (Côte d'Ivoire in the case of WAEMU). Therefore, the overall growth rate of the domestic population and labor force, $L(t)$, includes now both the fertility net of mortality effect and the migration effect:

$$
\frac{\dot{L}}{L}=n+M / L=n+m
$$

where $m$ is the net migration rate.

Domestic capital stock in the polar economy changes now as:

$$
\dot{K}=s F(K, \hat{L})-\delta K+\kappa M
$$

where $s$ is still the constant gross saving rate, $\kappa M$ is the human capital brought by immigrants. The growth rate of capital per effective worker in the context of open economies becomes:

6 The Solow model of economic growth is the starting point for all recent empirical analyses of growth convergence and the determinants of growth (Nerlove 2002, Arcand and d'Hombres 2002). 
$\psi_{\hat{k}}=s f(\hat{k}) / \hat{k}-[x+n+\delta+\xi(\hat{k})]$

where $\xi(\hat{k}) \equiv m(\hat{k})[1-(\hat{\kappa} / \hat{k})]$

Since migrants bring little stock of both physical and human capital, $\hat{\boldsymbol{\kappa}}<\hat{\boldsymbol{k}}$ would probably apply (Borjas 1999, Barro and Sala-i-Martin 1995) and if additionally $m>0$, the migration term adds to the effective depreciation rate to decelerate the growth of capital per effective worker in the receiving country. The latter results reinforce the convergence outcome when combined with the opposite effects on the sending country. ${ }^{7}$

The migration function $m(k)$ links migration rate positively to the present value of domestic wage rates in the polar country compared to the present value in the source country with the indicator for the wage gap being $\hat{k}$. For given conditions elsewhere, a higher value of $\hat{k}$ in the most advanced economy raises the domestic wage rate and tends accordingly to increase the migration rate, $m$. In a Cobb-Douglas production setting, the wage rate per unit of effective labor is $\hat{\boldsymbol{w}}=(\mathbf{1}-\alpha) \cdot \hat{\boldsymbol{A} \boldsymbol{k}}$, which is proportional to $\hat{\boldsymbol{y}}$ as well. A higher $\hat{k}$ raises the effective depreciation term in equation (4) of growth rate due to the positive relation between capital per effective labor in the host country and immigration rate.

However, the neoclassical results depend on the assumption about complementarity and substitutability between domestic and migrant labor as well as imperfections of the labor market. Despite continued migration from poorer to richer countries spatial inequalities in incomes seem to persist. The new economic geography literature proposes to include agglomeration effects. In these models, as labor migrates in response to a real wage differential the size of the market grows in the destination country and, as a result of scale economies, the real wage in the destination country increases rather than decreases (Venables 2003). The outcome is that real income differentials between origin and destination countries begin to grow, unless congestion

$7 \quad$ More details in the section about brain drain. 
costs dominate agglomeration benefits, so that the long run equilibrium is still favorable to convergence outcomes. Some models also show that at equilibrium the economy remains in the steady-state as a perpetual receiver of migrants, as far as there is mobility of labor. Braun (1993) observed a persistent unidirectional migration flow between U.S. states and under some specific condition, he found that the amount of human mobility turns out to be greater than the social optimum because migrants consider the average and not the marginal cost of moving. The author extended his migration model to show that an important explanation of convergence results still lies in capital and labor flows between economies. In his model, countries differ in a productive factor that is subject to a congestion externality and that is a local and rival public good. His model predicts that immigration has a negative effect on capital accumulation because an increase in population increases the congestion externality, which in turn lowers the rate of return on physical capital. Therefore, human mobility unambiguously speeds up convergence of product levels. In their empirical assessment of growth convergence, Kaufman, Swagel, and Dunaway (2003) show that Canadian federal transfers programs in its component of employment insurance ${ }^{8}$ system had a significant negative effect on output convergence by discouraging migration within Canadian provinces. This transfer program may have discouraged factor movements and other adjustment to economic conditions, thereby contributing to misallocations of productive factors and slower convergence.

Let now derive the convergence rate under labor mobility. I use a simple CobbDouglas production function and a log-linear migration term that writes as: $\xi(\hat{k})=m(\hat{k}) \cdot[1-(\hat{\kappa} / \hat{k})]=b \cdot\left[\log \left(\hat{k} / \hat{k}_{\text {world }}\right)\right]$ where:

$b$, the sensitivity of migration to income gap is positive or equal to zero

8 The Canadian federal employment insurance system simply provides temporary income support for individuals facing involuntary unemployment together with other social supports in training; selfemployment assistance as well as sickness, maternity and parental leave. The program benefits are based on hours worked during the previous year, past earnings, and previous use. The benefits of the system are differentiated depending on the level of unemployment within the regions and the generosity index for high unemployment regions is higher. 
and $\hat{k}_{\text {world }}$ represents the average capital intensity in other economies which, is conventionally a constant meaning that the world or the origin country is on average in the steady state. The speed of convergence that depends now on migration is obtained by log-linearizing the differential Equation in (4):

$\beta=(1-\alpha)(x+n+\delta)+b+b(1-\alpha) \log \left(\hat{k}^{*} / \hat{k}_{\text {world }}\right)$

As expected, the likely effects of human migration are therefore to accelerate growth convergence dynamics.

\section{Considerations of welfare effects in the source countries: beyond remittances and return migration}

The literature on the growth effects of migration has so far ignored the sending countries and the typical finding actually tends to argue that migration has a negative growth effect in the receiving country, unless migrants have a similar, or a higher, capital per person than natives (in which improbable case, $\hat{\kappa} \geq \hat{k}$ ). ${ }^{9}$ Because the converse is expected for the sending country, migration therefore is a powerful force working toward income convergence between capital-rich and capital-poor countries (Faini 2002). These results largely explain current restrictive immigration policies in the traditional receiving countries (USA, OECD and Arab Gulf countries) and account for the more marginal role of migratory flows in the globalization era. However, Hamilton and Whalley (1984) estimated that the liberalization of world labor markets could double the world income and that the highest gains will be for the developing countries.

The international mobility of skilled labor has recently become a key component of the global-based economy, especially in industrial countries. The highly talented workers are essentially becoming more globally mobile as goods, services and capital has become more globally mobile over time. Under this brain circulation perspective, the international mobility of skilled workers can generate global benefits by improving

9 Borjas (1999) found that immigrants are in average less skilled than US natives. 
knowledge flows and satisfying the demand for high-skilled workers where the demand is strongest (Harris and Schmitt 2003). The location of FDI, R\&D and skilled professionals are jointly determined: success at attracting one resource draws more of each.

The alternative conventional view on highly skilled emigration from developing to developed countries is extremely negative and tends to present the emigration of its skilled labor as a curse for source countries (Bhagwati and Hamada 1974). Therefore, the net benefits rely on how extensive is the brain drain.

To fully consider the effects of skilled migration on source country, it is important in this section to focus on the brain drain aspect that is summarized in the following question: ${ }^{10}$ Do highly educated professionals from landlocked WAEMU countries living in Côte d'Ivoire or elsewhere represent a sizable proportion of the pool of skilled workers in their countries of origin or too small figure to worry about?

\section{The New Economics of Brain Drain}

When productivity is fostered by both the individual's human capital and by the average level of human capital in the economy, individuals under-invest in human capital (Lucas, 1988). In the presence of such externalities, Stark (2003) showed that a strictly positive probability or prospect of migration, by raising both the level of human capital formed by optimizing individuals in the home country and the average level of human capital of nonmigrants in the country can enhance welfare and nudge the economy toward the social optimum. Therefore under a well-controlled restrictive migration policy that matches the optimal level of the signaling, the welfare of all workers is higher than in any alternative policy. The migration is a powerful policy tool to achieve such goal despite the apparent loss of human capital through the migration leakage and commonly known as brain drain.

Beine, Docquier and Rapoport (2003) summarized the preceding incentives-based results in a simple neoclassical growth model. Their model allows an empirical evaluation of the growth effects of the brain drain for the source countries of migrants.

10 Even though my data survey revealed a poor educational attainment of migrants from Burkina Faso, the question remains relevant. I am indeed interested in the relative skill profile of migrants regarding their home country and the brain drain is definitely an important issue if Cote d'Ivoire is supposed to develop. 
The model considers a small open developing economy where all markets are competitive, and a Cobb-Douglas type of technology as is the case in the preceding Solow model. The migration prospects tend to increase the expected return to human capital in the developing country (see equation 5 below), thus inducing more people to invest in education. People are initially endowed with a given level of inherited human capital, live for two periods, and make two decisions: whether to invest in education during their youth; and whether to migrate in adulthood. The success of the latter project is subject to a minimal degree of education $\bar{\theta}$. However, the immigration authorities randomly select migrants (in proportion $m$ ) among the appropriate skilled candidates.

A worker faces a cost $C\left(a, X^{h}\right)$ of forming human capital that is decreasing with his personal ability $a,{ }^{11}$ and also depends on a set of country-specific variables $X^{h}$ affecting human capital formation in a given country.

Measuring the return to education as the relative wage premium for the educated (relatively to the non-educated), the expected return to education, $V$, may be written as a weighted average of the relative return abroad, $w^{*}$, and the relative return in the domestic country, $w^{d}$.

$V=m_{w^{*}}+(1-m) w^{d}$ with $\frac{\delta V}{\delta m}>0$.

The equilibrium proportion of educated agents (with the prerequisite level $\bar{\theta}$ ) among the younger generation in the source country is given by $H=1-F\left(a^{*}\right)$; with $a^{*}$ denoting the ability of the worker indifferent as to whether to invest in education. Combining the latter cumulative distribution of ability and the objective function of workers $(V-C)$, one arrives to the results that an increase in the migration probability increases the expected return to education $V$, thus shifting the critical ability threshold to the left and decreasing $C$, the cost of human capital formation. The results is an increase in the equilibrium proportion of educated workers among which only few will be able to

11 The population distribution in the source country is described by the positive density function $f(a)$. 
migrate under a cooperative well-controlled south-north policy. The impact on welfare of the migration prospect is positive for everyone and the net effect of brain drain and brain gain in the presence of such migration mechanism can even be positive for the home country (Stark 2003).

At the macroeconomic level, the growth rate of human capital is positively affected by the post-migration proportion ( hum) of educated workers within the previous generation and number of other country specific variables $\left(X^{g}\right)$, such as the stock of physical capital. The equilibrium growth rate equation may thus be written as:

$$
g=g\left(h u m, X^{g}\right)
$$

Beine, Docquier and Rapoport (2003) concluded that emigration has two opposite effects: first, migration opportunities increase the expected return to education and, therefore, induce more people to invest in education ("brain effect"); second, emigration reduces the stock of human capital left in the sending country ("drain effect"). Data on brain drain variables inside WAEMU are now needed to operationalize the model main findings.

\section{Econometric approach and estimations}

While there are very few research on the brain drain, most of them are not econometric assessment and did not have data on any of the WAEMU countries. The most recent data set includes only those developing countries which received more than 500 million US dollars in official worker remittances in the year 2000. Bridging this research gap is the focus of the following sections based on the estimation of brain drain data set using the perpetual inventory method.

The link between migration and growth in sending countries is complex at empirical level. Besides the positive externalities internalized through migration prospect in the brain gain model to increase output in the home country, three other channels exist:

- Sustained migration flows may be associated with equally large flow of remittances that may help relieve the foreign exchange constraint in the home country. It should be noted that the new theory of brain drain does not focus on skilled migrants' 
remittances outcome, which is even not necessary for demonstrating the positive effect of migration prospect on the home country (Stark 2003).

- $\quad$ Migrants may return home after having acquired a set of productive skills with a beneficial impact on the growth prospects of their home country.

- $\quad$ Finally, "Diaspora externality" creates business and trade networks and promotes technology diffusion as well as FDI.

In contrast to these benefits, the conventional approach argues that:

- $\quad$ Any depletion of a country's stock of human capital is detrimental to its current and future economic performance, and brain drain is basically a negative externality imposed on those left behind. At the origin country level, the positive externalities of skilled migrants on home production, the education costs paid by home country and the education benefits are all lost.

The latter argument makes brain drain a zero-sum game, with the rich countries getting richer and the poor countries getting poorer.

Having this in mind, the econometrics of growth convergence analysis consists in comparing the performance of an economy without migration to the counterpart economy. This is achieved by comparing Burkina Faso that represents the most important sending country to Côte d'Ivoire relatively to Mali and the other WAEMU countries, the reverse holds when I consider France as receiving country.

\subsection{The brain drain estimates and empirical analysis}

\subsubsection{Estimates of schooling capital of migrants in Côte d'Ivoire}

The perpetual inventory method is used to generate the human capital dataset. Adams Jr. (2003) used the same methodology but he made the strong assumption that the two receiving regions considered (OECD and USA) have the same educational distribution of

migrants from each labor-exporting country, which does not allow a comparative econometric study of the different destinations. To compare the two destinations that have very different development level (Côte d'Ivoire and France), the human capital and brain drain data need to be estimated more accurately.

Three types of raw data are needed for estimating schooling capital of migrants living in Côte d'Ivoire: benchmark data on schooling attainment, school enrolment data 
and the share of the migrants' population of age group 15-19 (respectively 20-24) in the total population above 15 years old. Data were obtained from different sources that are mostly national censuses or surveys. ${ }^{12}$ The quinquennial data generated using the perpetual inventory method were compared and adjusted with annual data generated using multiple imputation method. The latter retains the assumption that the data were missing at random. Multiple imputation reflects the uncertainty of the estimates and a value is assigned for each missing measurement using maximum likelihood parameter estimates.

\subsubsection{Application of the perpetual inventory method to the domestic population}

The same estimations techniques were applied for each country's local human capital estimations. The estimates are less error-prone because the benchmark data were easier to gather for the countries using both national and international sources (UNESCO 1992, 2000; Barro-Lee updated dataset 2000; United Nations population division 2003; and World Bank 2000, 2002, 2003). Data are readily available for the yearly values of the school enrolment rates over the period considered 1970-2001 as well as for the share of population. The estimates are again tested by comparing the five-year data from the perpetual inventory method to the replicates built using multiple imputation applied for each year. To check for the accuracy of the data generated, sample countries that are similar were compared also, that is, the Sahelian countries Niger, Mali and Burkina Faso.

\subsubsection{Schooling capital of migrants in France}

Migration to France is the only case where estimations were not needed because data are available on migrants' educational attainment for the 7 countries covering the period 1925-1999. Detailed information on gender and age at arrival of the migrants were recorded also in the data set (INSEE 1999). Finally, additional data on migrants stocks for the years 1968, 1975, 1982, 1990 and 1999 and a time series of migrants' flows were used (Xavier Thierry 2003). However, unlike the preceding cases, no information exists

12 For enrolment rates, averages over the periods were considered due to extreme scarcity of statistics for some countries of interest. This assumes the enrollment likelihood for an average migrant of the sending country in Cote d'Ivoire. For schooling attainment, the nearest year available was retained in some cases like in Barro and Lee dataset. In few cases, the methods of multiple imputation or interpolation were applied. 
on the no-schooling category, which will be a constraint on the variables used in the regressions. The data generated for the destination France were also cross-checked using the information on the sending country's number of students in France (Bocquier, 2003) under the assumption that the latter constitutes a good proxy for higher schooling brain drain.

\subsubsection{Statistical analysis of the brain drain estimates}

Tables 1 and 2 present estimated migration rates by educational category for each labor exporting country. For all levels of education, Burkina Faso shows a higher incidence of brain drain to Côte d'Ivoire relative to the other WAEMU countries, whereas the opposite picture holds concerning migration to France. ${ }^{13}$ This confirms the position of Côte d'Ivoire as the main destination for Burkina Faso while France is relatively a more important destination for Mali. Therefore, Mali can play a role of reference group because both source countries are Sahelian with similar macroeconomic characteristics.

Focusing on the secondary and tertiary levels of education, the results in table 1 suggest that for both countries, the migration to Côte d'Ivoire is causing a significant brain drain (more than the conventional threshold of 10 percent of the group with at least a secondary education has migrated). The very high migration rate of the best educated from Burkina Faso simply indicates that the number of migrants with a tertiary education who leave this country represents a very high proportion of the local capital stock available with the same level of education. This is an important pressure on a meager resource. Even though the estimated figure for tertiary-educated migrants from Burkina Faso may overstate the true size of the brain drain from the country revealing some measurement error that the econometric estimations should account for, this important leakage calls for further discussions of the study context:

i) Keeping aside the measurement error problem, the calculations of brain drain for the migrant sub-group are affected by the definitional problem. Côte d'Ivoire defines immigrants as all persons born abroad who moved to the country, no matter if they subsequently acquired the nationality (Zanou 2001). The latter portion of immigrants who

13 Recall that the calculations for the brain drain to France are based on French Census data. Other calculations based on stocks of students as proxy for the tertiary level human capital provide similar ranking of the countries regarding the brain drain phenomenon. 
acquired the nationality of the host country can over-estimates the "effective" migrant population. ${ }^{14}$ Sometimes also figures made a confusion between immigrants and foreigners, the latter including the descendants of immigrants born in Côte d'Ivoire who are likely to be the best educated.

ii) During the period under study, Côte d'Ivoire developed the most successful educational policy inside WAEMU (while 76.9 percent of foreigners are illiterate, this ratio dropped to 57 percent in the Ivorian population (Zanou 2001)). ${ }^{15}$ This policy may have attracted a lot of students from Burkina Faso who acquired their education in their host country that has better education infrastructure compare to their place of origin ( 7 percent and 1 percent of enrollment rates in tertiary level are the respective achievements in 1998 for Côte d'Ivoire's and Burkina Faso's educational system according to the World Development Indicator 2003). However this second source of bias needs additional investigation because one of the channels of the increasing return migration is through the students sent home in Burkina Faso to study as result of the relative cheaper school fee.

iii) The pool of tertiary educated in the poorest source countries of WAEMU (Burkina Faso and Mali) is much smaller in absolute terms than the corresponding pool in the richer countries (Senegal, Benin and Togo). Nevertheless, the percentage share of the best educated in the total stock that migrated is probably much higher in the poor countries because they were more attracted by the stable development in Côte d'Ivoire during the period under study. There is a stronger reliance of poor sahelian countries on migration as a self-insurance mechanism and the consequences may be that poorer countries retrieve more from their meager educational resources inside the free movement zone of WAEMU.

iv) Finally a brain drain incidence above $70 \%$ is not unusual. It is actually interesting to compare with other findings. Using Carrington and Detragiache dataset and ranking countries according to the reliability of the data source, Beine, Docquier and Rapoport (2003) found the following impressive brain drain toward all destinations: Guyana

14 Stark (1991) explained how the integration of migrants as nationals of the host country may affect negatively their saving capacity and their willingness to remit.

15 School enrolment in official school is markedly higher in Côte d'Ivoire, on all levels whereas in the Burkinabè Sahel, kuranic education is nearly the only existing (survey 2002). This makes a relative disadvantage on the Ivorian urban labor market for the unskilled migrants (Hans 1996). 
(77.5\%), Jamaica (77.4\%), Ghana (25.7\%), Gambia (61.4\%), Tunisia (63.3\%), Algeria (55\%), and Senegal (47.7\%).

Both table 1 and table 2 have the specificity that the relative proportion of lowskilled migration from WAEMU countries is not very high. All the countries have a migration rate for those with a primary school that is less than 10 percent of their important domestic stock. The highest figure for primary school migrants is that of Burkina Faso ( 7 percent), followed by Mali (2 percent) in table 1.

Table 1: Average migration Rates to Côte d'Ivoire by Level of Educational Attainment, 15 years and above

\begin{tabular}{llll}
\hline \multicolumn{3}{l}{ Immigrants in Côte d'Ivoire as fraction of the individuals in the labor exporting country with the specified } \\
\multicolumn{4}{c}{ schooling level of educational attainment } \\
\hline \multirow{4}{*}{ Benin } & Primary & Secondary & Tertiary \\
& 0.01 & 0.03 & 0.05 \\
Burkina & $(0.003)^{*}$ & $(0.02)$ & $(0.03)$ \\
& 0.07 & 0.20 & 0.74 \\
Mali & $(0.01)(-)(--)$ & $(0.05)(-)(--)$ & $(0.65)(-)(--)$ \\
& 0.02 & 0.12 & 0.21 \\
Niger & $(0.015)$ & $(0.18)$ & $(0.13)$ \\
& 0.004 & 0.01 & 0.030 \\
Senegal & $(0.003)$ & $(0.005)$ & $(0.013)$ \\
& 0.004 & 0.004 & 0.005 \\
Togo & $(0.001)$ & $(0.003)$ & $(0.0035)$ \\
& 0.01 & 0.008 & 0.014 \\
& $(0.0003)$ & $(0.005)$ & $(0.005)$ \\
\hline
\end{tabular}

*standard deviation in parentheses

(-) (--): outcome of mean comparison for Brain Drain at the specified school level using Two-sample $t$ test with unequal variances. (-) indicates significant brain drain from Burkina Faso relative to Mali; (-- ) indicates significant drain from Burkina Faso relative to all other WAEMU countries.

$(+)$ and $(++)$ if the respective opposite holds.

Source: Own calculations using the perpetual inventory method.

It appears from this descriptive statistical analysis that recorded legal migration from WAEMU involves relatively more movement of better educated people, people who are more educated than those who remain at home. Overall, these statistical patterns are in line with previous studies. Sub-Saharan Africa lost 30 percent of its skilled personnel between 1960 and 1987. Jamaica has to train 5 doctors in order to keep 1 (Faini, 2002), representing a leakage of 80 percent of the national resources allocated. For Ghana alone, more than 15 percent of the home country population with a tertiary education has migrated to the US. Carrington and Detragiache (1998) confirmed that migration rates distribution is heavily skewed toward educated people. Migrants to the United States tend 
to be better educated than the average person in their home country, and the proportion of very highly educated people who migrate is particularly high. Kanbur and Rapoport (2003) reported that "these trends seem to have accelerated since the 1960s. In 1975, the United Nations estimated the total number of highly skilled South-North migrants for 1961-72 at only 300,000. Less than a generation later, in 1990, the U.S. Census revealed that there were more than 2.5 million highly educated immigrants from developing countries residing in the U.S. alone, excluding students!"

Table 2: Average migration Rates to France by Level of Educational Attainment, 15 years and above

\begin{tabular}{llll}
\hline \multicolumn{3}{l}{ Immigrants in France as fraction of the individuals in the labor exporting country with the specified } \\
schooling level of educational attainment & \multicolumn{2}{l}{ Tertiary } \\
\hline \multirow{3}{*}{ Benin } & Primary & Secondary & 0.35 \\
& 0.002 & 0.007 & $(0.91)$ \\
Burkina & $(0.007)^{*}$ & $(0.003)$ & 0.023 \\
& 0.0004 & 0.003 & $(0.01)(+)(++)$ \\
Mali & $(0.00015)(+)(++)$ & $(0.0005)(+)(++)$ & 0.05 \\
& 0.007 & 0.045 & $(0.016)$ \\
Niger & $(0.002)$ & $(0.052)$ & 0.014 \\
& 0.0003 & $(0.002)$ & $(0.004)$ \\
Senegal & $(0.0002)$ & $(0.005)$ & 0.055 \\
& 0.005 & 0.021 & $(0.016)$ \\
Togo & $(0.002)$ & $(0.006)$ & 0.14 \\
& 0.0005 & 0.012 & $(0.19)$ \\
Côte d'Ivoire & $(0.0001)$ & $(0.012)$ & 0.024 \\
& 0.0006 & 0.003 & $(0.01)$ \\
\hline
\end{tabular}

Same notes as in Table 1. 


\subsection{The econometric Analysis}

Now, the brain drain data is used for an econometric analysis of the augmented Solow model. Faini's approach was based on pooled OLS regression that poses enormous problems of countries' unobserved heterogeneity. Both Nerlove (2002) and Arcand and d'Hombres (2002) argued that most of the recent investigations of growth convergence and the rate of convergence are flawed by their failure to account for the inconsistencies of single cross-section or panel studies in a dynamic context. ${ }^{16}$

In the current study, a growth convergence estimation that highlights the key role of human capital (table 3) and "brain drain" (table 4) is carried out using panel data methods. Then, the migration theory is used to infer how the skilled composition of migration affects education and remittances flows in the sending country. Arcand and d'Hombres (2002) identified in the Solow setting two potential sources of unobserved effects that are country-specific initial levels of technology and its rates of technological change. The within and first-difference procedures usually account for the first source of bias, controlling for differences stemming from the heterogeneity across countries in the initial value of technology. The second potential source of bias constituted by countryspecific rates of technological progress can be solved by moving to second-differences and assume multiplicative country-specific fixed effects to account for the remaining source of heterogeneity. However, these methods of within procedure or first differences while solving the unobserved heterogeneity problems may result in the additional problem of lack of precision or unexpected signs in growth regressions. The latter usually lie in the low variability of the human capital variable used, once first differencing is performed.

Therefore alternative strategies are proposed in the literature of panel data. To account for eventual time-invariant variables or the similar problem of low variability, Wooldridge (2002) proposed to include time dummies if they are significant. By interacting time-constant variables and time period dummies, the differences in partial

16 The authors proposed new methods of estimations. Nerlove (2002) devised a new method of maximum-likelihood estimation based on the density of the observations unconditional on the starting values of the dependent variable and he argued that the usual procedures for doing feasible Generalized Least Squares (GLS) or for obtaining starting values for Maximum Likelihood (ML) are seriously flawed. Arcand and d'Hombres (2002) proposed a new estimator that solves the problem of low variability resulting from estimations in first differences. 
effects of the time-constant variables relative to the base period can be identified. This allows to test whether the effects of time-constant variables have changed over time. In this case, however, the estimates are not the actual size of the coefficient of the intercept and other time-constant variables. The Hausman-Taylor (HT) approach is an alternative when one needs to assess time-invariant variables effects in a context of unobserved heterogeneity with weak instruments problem. Arcand and d'Hombres (2002) proposed a new estimator in a context of low variability and measurement error that is the HausmanTaylor procedure revised in favor of an improved set of instruments that are deviations to the mean estimated over a subset of the time period. After deleting the observation at time $t$ for each individual, they transform a variable into its deviations lagged one period with respect to its individual mean measured from $\mathrm{t}-1$ backwards. This procedure purges the right-hand side variable that is correlated with the unobserved effects from its affected component. The objective is to precisely identify the impact of particular timevarying variables, correlated with the individual effects, whose variance falls dramatically once a first-differencing is performed. Additionally, the estimator identifies the impact of time-invariant variables while controlling for individual effects. The new method fits particularly to the problem of the logarithm of human capital in a growth regression because the variable becomes "almost time-invariant" after first differencing. An advantage of the Arcand-d'Hombres method is to take into account the correlation between the time varying variable and the time varying component of the error term.

The same issue of low variability is present in the procedure of the current estimations because the regressions are based on human capital variables. As mentioned earlier, estimation methods based on the standard within procedure or first differences solve the problem of unobserved heterogeneity but they result in the additional problem of lack of precision or unexpected signs in growth regressions. The problem of the low variability of the human capital variable once first differencing is performed is likely to occur in the specific context where the number of cross-sectional units is small. The WAEMU convergence model consists of an unbalanced panel of 6 individual countries when the receiving country is Côte d'Ivoire ( 7 otherwise) ${ }^{17}$ and an average of 15 year

17 As indicated in tables 1 and 2, Guinea Bissau is missing due to lack of data. The country has joined the Union only recently. 
time periods. ${ }^{18}$ In this scheme, most of the usual panel econometric methods fail because they are valid only asymptotically, as the number of countries in the data set become large. These standard methods can produce misleading results when applied to panel data with a small number of units (see regression 1 in table 3). ${ }^{19}$ Therefore, the model including human capital variables (table 3) is first estimated using Least Squares Dummy Variables (LSDV) with panel corrected standard errors, which performs well in the current circumstances and allows recovering countries specific effects (Koenker, 2001) as presented in regression (2) of table 3. Estimating Equation 1 (see regression (1) in table 3) requires first to perform a within-transformation of the variables before applying the panel corrected standard errors estimator. This transformation causes no problem of identification in the estimation process if there are no time-invariant variables in the model. The descriptive statistics of the variables used in the study are presented in table A1-1 (see Appendix A1). The results in table 3 represents a standard convergence equation, in which national GDP growth (in per capita terms) depends on the previous year's level of national per capita GDP (Kaufman, Swagel, and Dunaway 2003). The Barro-Lee type of human capital estimates, which has been successful in the growth literature, are also included (Hultberg, Nadiri and Sickles 1999). ${ }^{20}$ An additional control variable is the log of the investment ratio minus the population growth rate that reveals the impact of investment and population growth (Arcand and d'Hombres 2002). Finally, the estimation of convergence in a context of open economies should include migration effects for all countries considered (both tables 3 regression 2 and 4). Therefore, the estimated brain drain variables and the impact of remittances per capita are included. ${ }^{21}$ The brain drain variables are derived from the estimations of human capital as indicated in the previous section. The convergence equation tested a number of country-specific factors (table 3, regression 2).

18 Attempts to control for business cycles dynamics and temporary external shocks by considering fiveyear periods averages did not give good results.

19 The bias of fixed-effects models using the standard within-estimator in the estimation of dynamic panel models is apparent in Nerlove (2002). The use of such methods biases therefore the test for convergence. Also see Beck and Katz (1995).

20 Krueger and Lindahl (2001) provide a good discussion of the different manners in which human capital is entered into growth Regressions.

21 The remittances data used in the study come from the International Monetary Fund, Balance of Payments Statistics Yearbook. For the study countries, official worker remittances have increased in real terms faster than the annual rate of growth performance. 
In the outputs of the standard augmented Solow model (regression (1) in table 3), there is a significant convergence effect as expected. The annual rate of convergence toward the steady-state in the WAEMU zone is evaluated to be 2.40 percent.

Once the migration effects are accounted for through brain drain (cf. table 4), the convergence process speeds up to 3.25 percent (regression 3). As indicated by the theory, labor mobility tends to speed up an economy's convergence to its steady-state position. In a worldwide cross-country study with international migration, Barro and Sala-i-Martin (1995) found that the empirical estimates of the $\beta$-convergence amounts to 2.3 percent per year across countries and they concluded that the inclusion of migration suggests an increase (by roughly 10 percent) in the convergence speed.

There is a positive significant impact of investment in regression (1) of table 3 whereas the local human capital appears to be strongly positive at primary school level. At the same time, the active population with no schooling contributes also to the economic growth, which could be explained by the strong importance of the traditional non-human capital intensive agricultural sector inside the WAEMU (regression 1, table 3). As expected, the latter has a smaller impact than the primary level schooling capital.

However, while capital investment and the source country local human capital effect appear positive as expected in the first equation, these effects either disappeared or flipped sign when countries effects are controlled for (regression 2, table 3). These are unexpected results that bring up the usual problem of measurement error in human capital as well as endogeneity problems, which I dealt with using appropriate instrumental methods in table 4 . The brain drain variables concerning migration in the specific destination of Côte d'Ivoire are those estimated using the permanent inventory method and suspected of measurement errors (see previous section). Therefore, the latter are instrumented. Recall that the brain drain data for the destination France are not suspected because gathered from the French National Census. The initial level of GDP per capita is predetermined and as suggested by Anderson and Hsiao (1981) it should also be

$22 \gamma_{0}=1-\exp (-\beta \tau)$ where $\gamma_{0}$ is the positive part of coefficient $\gamma_{\text {of the initial level of GDP per }}$ capita, $\tau$ is the time that elapses between two time periods and $\beta$ the annual rate of convergence. 
instrumented using its two-period lag. ${ }^{23}$ Two important econometric tests have been conducted for the final outputs presented in regression 3 of table 4. First, a Hausman test is conducted to ascertain whether the random error is correlated with the individual effects (Test 1, Appendix A2). A second test checked if the difference in the countries effects is statistically significant (Test 2, Appendix A2). The tests respectively showed that the fixed effects model is preferred and that the null hypothesis of common intercept for all WAEMU countries is rejected.

I finally can proceed with the model retained for brain drain with fixed-effects (regression3 of table 4), which is estimated using the instrumental two-step GMM estimation method that controls for arbitrary heteroskedasticity. The standard instruments of a Hausman-Taylor (HT) procedure are constructed using the right hand side variables, the latter being within-transformed and averaged by panel. These instruments have, however, been lagged two periods to account for potential predeterminedness of the variables. ${ }^{24}$ Additionally, the HT instruments set are improved on by including external instruments that are the human capital variables lagged two periods.

To summarize the last estimation procedure, the latter external instruments, the exogenous regressors (investment and brain drain toward France) and the excluded instruments (two-period lagged endogenous variables as constructed above) are the "instruments", and the brain drain to Côte d'Ivoire together with the initial GDP are the endogenous variables (see Appendix A4-1). This estimator out-performed the standard Arellano-Bond estimator, which is valid only for very large number of panels. The current choice of instruments set took into account the findings in the GMM literature, which has shown that using too many instruments for a given sample size in a GMM estimator can produce significant finite sample bias (Wooldridge 2001).

23 In panel data models with predetermined variables, standard Fixed-effects estimators are inconsistent. One needs to use robust instrumental variables estimators similar to the one proposed by Anderson and Hsiao (1981), which provide consistent estimates.

24 As indicated in the Nakamura and Nakamura's test (see Test 3 in table A2-1, Appendix), the HT assumption of exogeneity failed. 
Table 3: Growth convergence: local human capital impact

\begin{tabular}{|c|c|c|}
\hline & $\begin{array}{l}\text { (1) Fixed effects, } \\
\text { correlated panels corrected } \\
\text { standard errors (PCSEs) }\end{array}$ & $\begin{array}{l}\text { (2)LSDV, correlated } \\
\text { panels corrected standard } \\
\text { errors (PCSEs) }\end{array}$ \\
\hline & $\begin{array}{l}\text { Annual per capita GDP } \\
\text { growth (constant local } \\
\text { currency) }\end{array}$ & $\begin{array}{l}\text { Annual per capita GDP } \\
\text { growth (constant local } \\
\text { currency) }\end{array}$ \\
\hline Constant price initial GDP per capita (Summer- & -0.024 & -0.040 \\
\hline Heston) & $(-4.54) * *$ & $(-3.89) * *$ \\
\hline $\log$ of the investment ratio minus the population & 4.341 & 4.632 \\
\hline growth rate & $(2.24)^{*}$ & $(1.59)$ \\
\hline Estimated local human capital (no schooling) & $\begin{array}{l}125.808 \\
(3.80)^{* *}\end{array}$ & \\
\hline $\begin{array}{l}\text { Estimated local human capital (primary } \\
\text { schooling) }\end{array}$ & $\begin{array}{l}155.029 \\
(3.60)^{* *}\end{array}$ & \\
\hline Estimated local human capital (tertiary schooling) & $\begin{array}{l}-87.224 \\
(-0.47)\end{array}$ & \\
\hline Logarithmic total remittances flows per capita & $\begin{array}{l}-1.409 \\
(-0.95)\end{array}$ & \\
\hline Brain drain France (tertiary) & & $\begin{array}{l}147.579 \\
(0.87)\end{array}$ \\
\hline Brain drain France (secondary) & & $\begin{array}{l}-4,375.746 \\
(-3.33)^{* *}\end{array}$ \\
\hline $\begin{array}{l}\text { Estimated local human capital (secondary } \\
\text { schooling) }\end{array}$ & & $\begin{array}{l}-288.780 \\
(-2.54)^{*}\end{array}$ \\
\hline $\begin{array}{l}\text { Estimated human capital of migrants in RCI } \\
\text { (tertiary schooling) }\end{array}$ & & $\begin{array}{l}-815.583 \\
(-2.99)^{* *}\end{array}$ \\
\hline $\begin{array}{l}\text { Estimated human capital of migrants in RCI } \\
\text { (secondary schooling) }\end{array}$ & & $\begin{array}{l}75.903 \\
(2.04)^{*}\end{array}$ \\
\hline human capital of migrants in France (higher & & 28.614 \\
\hline schooling) & & $(0.97)$ \\
\hline $\mathrm{id}==$ Benin & & $\begin{array}{l}85.030 \\
(2.85)^{* *}\end{array}$ \\
\hline $\mathrm{id}==$ Burkina & & $\begin{array}{l}50.410 \\
(2.41)^{*}\end{array}$ \\
\hline $\mathrm{id}==$ Mali & & $\begin{array}{l}150.666 \\
(3.19)^{* *}\end{array}$ \\
\hline $\mathrm{id}==$ Niger & & $\begin{array}{l}40.145 \\
(2.24)^{*}\end{array}$ \\
\hline $\mathrm{id}==$ Senegal & & $\begin{array}{l}197.129 \\
(3.41)^{* *}\end{array}$ \\
\hline $\mathrm{id}==$ Togo & & $\begin{array}{l}107.263 \\
(2.86)^{* *}\end{array}$ \\
\hline Constant & $\begin{array}{l}-92.542 \\
(-3.04)^{* *}\end{array}$ & \\
\hline Observations & 120 & 62 \\
\hline Number of country unique identifier & 7 & 6 \\
\hline
\end{tabular}


Concerning the suitability of the set of instruments, I conducted preliminary descriptive analysis of correlation and variability (Tables A3-1 and A3-2 in Appendix). Table A3-1 in Appendix observes that the correlations among all variables are strong enough and it can be expected that the instruments are suitable for the current estimations. Because the test indicated sufficient correlations, the instruments can be expected to allow identifying the coefficients of the endogenous variables (Stock, Wright, and Yogo 2002). In Table A3-2, the variables are inspected to see if they exhibit sufficient within-panel variation to serve as their own instruments.

Finally the output presented in table 4 passes the Hansen-Sargan test for overidentifying restrictions. Hence, the null assumption of valid instruments cannot be rejected (Table 4. For details on the test, see Appendix A4). There is no second order autocorrelation in the first-differenced idiosyncratic errors. ${ }^{25}$

Table 4: Growth convergence: Brain drain impact

\begin{tabular}{llll}
\hline & $\begin{array}{l}\text { (1) Fixed effects (within) } \\
\text { with correlated panels } \\
\text { corrected standard errors }\end{array}$ & $\begin{array}{l}\text { (2) Fixed-effects } \\
\text { (within) IV regression }\end{array}$ & $\begin{array}{l}\text { (3) Fixed-effects (within) } \\
\text { IV regression, } \\
\text { GMM estimation }\end{array}$ \\
\hline & $\begin{array}{l}\text { Annual per capita GDP } \\
\text { growth (constant local } \\
\text { currency) }\end{array}$ & $\begin{array}{l}\text { Annual per capita GDP } \\
\text { growth (constant local } \\
\text { currency) }\end{array}$ & $\begin{array}{l}\text { Annual per capita GDP } \\
\text { growth (constant local } \\
\text { currency) }\end{array}$ \\
\hline Initial GDP pc capita & -0.032 & -0.030 & -0.032 \\
log of the investment minus & $(-6.13)^{* * *}$ & $(-4.14)^{* * *}$ & $(-3.84)^{* * *}$ \\
population growth rate & $(1.012$ & 3.829 & 5.856 \\
Brain drain Côte d'Ivoire & -114.429 & $(1.89)^{*}$ & $(2.88)^{* * *}$ \\
(no schooling) & $(-2.81)^{* * *}$ & -82.005 & -122.322 \\
Brain drain Côte d'Ivoire & -77.754 & $(-1.58)$ & $(-3.17)^{* * *}$ \\
(secondary) & $(-1.88)^{*}$ & 34.029 & -151.215 \\
Brain drain Côte d'Ivoire & 5.585 & $(0.36)$ & $(-3.83)^{* * *}$ \\
(tertiary) & $(0.60)$ & -6.389 & 7.282 \\
Brain drain France (tertiary) & -34.432 & $-0.51)$ & $(1.21)$ \\
& $(-0.89)$ & -56.385 & 190.238 \\
Brain drain France & -350.579 & $(-1.34)$ & $(3.00)^{* * *}$ \\
(secondary) & $(-2.02)^{* *}$ & -551.462 & 145.499 \\
Constant & 45.383 & $(-1.92)^{*}$ & $(1.66)^{*}$ \\
Observations & $(5.73)^{* * *}$ & 40.135 & 21.770 \\
\hline Z statistics in parentheses $*$ significant at $10 \% * * *$ significant at $5 \% * * * *$ significant at $1 \%$ & $(3.20)^{* * *}$ \\
\hline
\end{tabular}

z statistics in parentheses $*$ significant at $10 \% ; * *$ significant at $5 \% ; * * *$ significant at $1 \%$ Hansen J statistic (overidentification test of all instruments): 12.843

25 While the presence of first order autocorrelation found in the differenced residuals of the model does not imply that the estimates are inconsistent, the presence of second order autocorrelation would imply the latter problem (Arellano and Bond, 1991). 


$$
\text { Chi-sq(9) P-val }=0.16984
$$

Before interpreting the final outputs in the last column, let analyze the first results in Table 4. The first regression (fixed effects with correlated panels corrected standard errors) indicates strong convergence effects. However, the investment becomes significant only when instrumental variables with GMM estimation are used (regression 2 and 3).

In the final outputs, the brain drain effects appear significantly negative when migration destination is Côte d'Ivoire while the reverse significantly holds for France (see final regression 3). Therefore, one can conclude that the brain gain happens only when WAEMU countries choose an industrialized country as destination. This seems to support Venables (1999) conclusion that an African country should prefer a 'north-south' type of integration agreements. However, unlike Venables there is a strong income convergence effects inside the WAEMU, which simply support that the benefits of the Union are not captured by the sole advanced economies.

Migrants who leave their home country for Côte d'Ivoire with no schooling have a negative impact on the regional growth as these people may be more productive in their country relative to the more human capital intensive economic sectors of Côte d'Ivoire. As it was discussed earlier, schooling rate is markedly higher in Côte d'Ivoire, on all levels, as compared to the source countries (Hans 1996). In the latter, the illiteracy rate is above 75 percent, that is, nearly 50 percent higher than in Côte d'Ivoire. These results suggest that the least costly migration for the Sahelian countries may be seasonal. The latter is compatible with rain-fed agriculture. Another implication is that source countries may want to develop irrigation and agricultural investments that will optimize the impact of their important rural labor force at home (effects of unskilled labor in table 3). However, the regional brain drain at the secondary schooling level appears with strongly negative impact, which supports the argument, that intra-regional brain drain may not favor growth. There is no brain gain when the movement of skilled migrants is toward the polar country, Côte d'Ivoire. Contrasting with the regional skilled migration, for the countries whose migration is directed toward France, the positive effect of a well controlled policy of brain drain appears at higher and at secondary schooling level as shown in regression 3 of table 4 . These two results do not contradict the brain gain 
theory. As it has been shown in section 3, for the level of welfare of the sending country to increase, the destination should be very attractive in terms of expected gains and the source country's migration policy should be designed so that the probability of migration is not above a certain threshold estimated around 10 percent (Adams Jr 2003). Part of the education investment in the source country actually acts through those who migrate to advanced countries, send back remittances and further incentives for investing in human capital in the sending country.

The negative outcomes of the regional brain drain concern primarily a country like Burkina Faso because the statistical tests have indicated it has the highest brain drain to Côte d'Ivoire. Tables 1 and 2 clearly showed that the brain drain to Côte d'Ivoire of the best educated from Burkina Faso is above the conventional threshold whereas the other WAEMU countries do not suffer a severe brain drain toward France where their migration is concentrated.

Existing estimates in the migration literature suggest that remittances alone more than offset the net welfare loss usually derived from the welfare impact of migration. However, we do not find any significant effect of remittances in our regressions, which may indicate that its effects are captured through the investment variable. The nonsignificant effect of remittances may also reveal some of the negative effects of the Ivorian crisis during the last decade. Dore, Benoit, and Engmann (2003) established that the spillover effect of the Ivorian current and past crisis on neighboring countries could take place through the trade channel (depending on the size and the geographical proximity of the neighbor) and also the capital flows and current transfers in a similar way as for the Asian crisis. ${ }^{26}$ In Burkina Faso, workers' remittances fell from CFAF 50.3 billion to 30 billions CFA francs in 2002, mainly as a consequence of the repatriation ${ }^{27}$ of economic migrants from Côte d'Ivoire and the worsening economic situation in the country.

26 See Ades and Chua (1993) for some theoretical foundations of the negative impact of regional instability on the economic growth of neighboring countries and Guillaumont, Guillaumont and Brun (1999) about the negative effects of domestic instability.

27 In the aftermath of the 1999 Coup d'Etat, several thousands of migrant agricultural workers mainly Burkinabe and Malians had to leave Tabou (in the South) because of ethnic clashes with indigenous Krou population. The surge in forced return migration is currently an important regional issue. 


\section{Conclusion}

Since the last decade an increasing of attention has been paid to the ambiguous relationship between international migration, brain drain, and economic growth, but few papers analyzed the growth impact of skilled migration. This paper filled the research gap by building the first data set on brain drain concerning seven countries of the western African Union (WAEMU) and highlighted the size of the brain drain toward Côte d'Ivoire and France. The paper has gone beyond the usual descriptive analysis and the implications on growth convergence have been evaluated.

The positive message is the finding that there exists a convergence path inside WAEMU that leads to the conclusion that polar countries are not the only beneficiaries of the Union. However, the migration of skilled personnel speeds up this process of convergence only when it is outward-oriented, that is toward developed countries like France. Therefore, migration can be used as a powerful force working toward income convergence between capital-rich and capital-poor countries.

If the traditional receiving countries (USA and other OECD countries and Arab Gulf countries) care about the welfare of poor countries, they should collaborate in the design of carefully controlled immigration policies (monitoring thereby the size of brain drain) that matches the optimal welfare level and includes the migratory policy in the globalization arena.

Concerning the specific case of Burkina Faso, the main exporter of labor to Côte d'Ivoire, it out-performs only Niger that does not have migrants flows directed to France. Burkina Faso seems to lose a critical proportion of the meager pool of skilled workers through migration to Côte d'Ivoire. But the brain loss is as important as the unskilled year-long migration because the latter is a loss of agricultural earnings, suggesting that policy-makers should invest in the rural sector for agricultural innovation, truck farming during the slack season and local off-farm activities. 


\section{REFERENCES}

Adams Jr, R. H. 2003. International Migration, Remittances and the Brain Drain: A Study of 24 Labor-Exporting Countries, Policy Research Working Paper 3069, World Bank, Washington DC. http://econ.worldbank.org/files/27217_wps3069.pdf.

Ades, A., and H.B. Chua. 1993. Regional Instability and Economic Growth: Thy Neighbor's Curse. Yale University Economic Growth Center. Discussion Paper No 704, 38p.

Anderson, T. and C., Hsiao (1981), "Estimation of Dynamic Models with Error Components," Journal of the American Statistical Association 76: 598-606.

Arcand, J.L., and B. d'Hombres. 2002. Explaining the Negative Coefficient Associated with Human Capital in Augmented Solow Growth Regressions, CERDI, Clermont Ferrand. http://www.cerdi.org/P Perso/PP Home.asp?IDUSER=arcandandSubmit=OK, 40 p.

Bhagwati, J.N. and K. Hamada. 1974. The brain drain, international integration of markets for professionals and unemployment. Journal of Development Economics. 1 (1): 19-42.

Barro, R.J., and X. Sala-i-Martin. 1995. Economic growth. Cambridge, Massachusetts, London, England: The MIT Press. 544p.

Barro, R. J., and X. Sala-i-Martin.1992. Regional growth and migration: a Japan-United States Comparison. Journal of the Japanese and International Economies 6: 312-346.

Barro, R., and J-W Lee. 2000. Data Set on Educational Attainment of the Total Population Aged 25 and Over. Center for International Development at Harvard University, www.ksg.harvard.edu/CID

Beck, N., and J.N Katz. 1995. What To Do (and Not to Do) with Time-Series Cross-Section Data. American Political Science Review 89 (3): 634-647.

Beine, M., F. Docquier and H. Rapoport. 2001. Brain drain and economic growth: Theory and evidence. Journal of Development Economics, 64 (1): 275-89.

Beine, M., F. Docquier and H. Rapoport. 2002. Brain drain and LDCs' growth: Winners and Losers. CREDPR Working Paper Series No 129, Stanford University.

Blanchard, O. 1989. Lectures on Macroeconomics. Cambridge, MIT Press. Quoted in Barro, R. J., and X.Sala-i-Martin.1995. Economic growth, Cambridge. The MIT Press.

Borjas, G.J. 1999. Heaven's door: Immigration policy and the American Economy. Princeton: Princeton University Press. 
Braun, J. 1993. Essays on economic growth and migration. Havard University, PhD Thesis.

Dore, O., A. Benoit, and D. Engmann. 2003. Regional impact of Cote d'Ivoire's sociopolitical crisis: An assessment: http://www.imf.org/external/pubs/ft/wp/2003/wp0385.pdf.

Faini, 2002. Migration, Remittances and Growth. http:/www.wider.unu.edu/conference/conference-2002-3/conference\%20Papers/faini.pdf, $21 \mathrm{p}$.

Guillaumont, P., S. Guillaumont, and F. Brun. 1999. How Instability Lowers African Growth. Journal of African Economies 8(1).

Hamilton, B. and J. Whalley. 1984. Efficiency and Distributional Implications of Global Restrictions on Labour Mobility: Calculations and Policy Implications. Journal of Development Economics, 14: 61-75.

Hans, E. 1996. Are West-African Immigrants Discriminated in Côte d'Ivoire?. Regional Program on Enterprise development (RPED). http://www1.worldbank.org/rped/documents.asp?action=search\&clear=true

Harris, R. and N. Schmitt. 2003. The consequences of increased labor mobility within an integrating North America. In North American linkages: Opportunities and challenges for Canada. Edited by R. Harris, pp. 313-352.

Hultberg, P., I. Nadiri, and R. Sickles. 1999. An international comparison of technology adoption and efficiency: A dynamic panel model. Annales d'Economie et de Statistique, 55-56: 449-474. Quoted in Sevestre, P. 2002. Econométrie des données de panel. Paris: Dunod, p.11.

INSEE.1999. Recensement de la population, France.

International Monetary Fund (IMF). Balance of Payments Statistics Yearbook (several years), Washington, DC.

Kanbur, R and H. Rapoport. 2003. Migration selectivity and the evolution of spatial inequality. http://www.arts.cornell.edu/poverty/kanbur/KanRap.pdf.

Kaufman, M., P. L. Swagel, S. V.Dunaway. 2003. Regional Convergence and the Role of Federal Transfers in Canada. http://www.imf.org/external/pubs/ft/wp/2003/wp0397.pdf

Koenker, R. 2001. Panel Data. Lecture 13, mimeo, University of Illinois at Urbana-Champaign. 
Krueger, A., and M. Lindahl. 2001. Education for Growth: Why and For Whom? Journal of Economic Literature, 39:1101-1136.

Nerlove, M. 2002. Essays in panel data econometrics. Cambridge: Cambridge University Press.

Stock, J. H., J. H. Wright, and M. Yogo. 2002. A survey of weak instruments and weak identification in generalized method of moments. Journal of Business and Economic Statistics, 20 (4): 518-529.

Venables, J. A. 1999. Regional Integration Agreements: a force for convergence or divergence ? Working Papers 2260, World Bank - Country Economics Department.

Venables, A. 2003. Spatial disparities in developing countries: cities, regions and international trade, Working Paper, London School of Economics.

Wooldridge, J. 2001. Applications of Genelaized Method of Moments Estimation. Journal of Economic Perpectives 15 (4): 87-100.

Wooldridge, M. J. 2002. Econometric analysis of cross section and panel data. Cambridge, Massachussets: The MIT press, 752p.

Thierry Xavier. 2003. Flux de migrants 0uest-Africains en France, INED.

United Nations Educational, Scientific and Cultural Organization (UNESCO).1992. Educational data. Statistical Institute.

United Nations Educational, Scientific and Cultural Organization (UNESCO). 2000. Statistical yearbook.

United Nations Population Division (UNDP). 2003. Population data.

World Bank. 2000. World Development Indicators.

World Bank. 2002. World Development Indicators

World Bank. 2003. World Development Indicators.

World Bank. 2003. Global Development Network data.

Zanou, B. 2001. Migrations. Rapport d'Analyse du RGPH-98. Institut National de la Statistique (INS) Côte d'Ivoire. 
APPENDICES

A1 Descriptive statistics

Table A1-1 Univariate summary statistics of variables

\begin{tabular}{|c|c|c|c|c|c|}
\hline Variable & Obs & Mean & Std. Dev. & Min & Max \\
\hline Stocks of students in France & 64 & 1169.86 & 1004.946 & 19 & 3545 \\
\hline Migrants of the country in France & 187 & 14908.26 & 14958.4 & 244 & 60975 \\
\hline $\begin{array}{l}\text { Share of migrants in France with primary } \\
\text { level }\end{array}$ & 280 & 0.28 & 0.14 & 0.09 & 0.51 \\
\hline $\begin{array}{l}\text { Share of migrants in France with } \\
\text { secondary level }\end{array}$ & 280 & 0.40 & 0.05 & 0.29 & 0.50 \\
\hline $\begin{array}{l}\text { Share of migrants in France with tertiary } \\
\text { level }\end{array}$ & 280 & 0.32 & 0.14 & 0.10 & 0.54 \\
\hline $\begin{array}{l}\text { Estimated share of stayers with no } \\
\text { schooling. }\end{array}$ & 294 & 0.66 & 0.23 & 0.08 & 0.99 \\
\hline $\begin{array}{l}\text { Estimated share of stayers with primary } \\
\text { schooling. }\end{array}$ & 321 & 0.25 & 0.16 & 0.001 & 0.65 \\
\hline $\begin{array}{l}\text { Estimated share of stayers with secondary } \\
\text { schooling. }\end{array}$ & 266 & 0.08 & 0.08 & 0 & 0.49 \\
\hline $\begin{array}{l}\text { Estimated share of stayers with higher } \\
\text { schooling. }\end{array}$ & 336 & 0.0087 & 0.0092 & 0 & 0.05 \\
\hline $\begin{array}{l}\text { Share of migrants in Côte d'Ivoire with } \\
\text { no schooling }\end{array}$ & 84 & 0.69 & 0.16 & 0.45 & 0.92 \\
\hline $\begin{array}{l}\text { Share of migrants in Côte d'Ivoire with } \\
\text { primary level }\end{array}$ & 84 & 0.17 & 0.12 & 0.011 & 0.41 \\
\hline $\begin{array}{l}\text { Share of migrants in Côte d'Ivoire with } \\
\text { secondary level }\end{array}$ & 84 & 0.11 & 0.086 & 0.017 & 0.39 \\
\hline $\begin{array}{l}\text { Share of migrants in Côte d'Ivoire with } \\
\text { higher level }\end{array}$ & 84 & 0.035 & 0.011 & 0.007 & 0.058 \\
\hline $\begin{array}{l}\text { Annual GDP growth per capita (constant } \\
\text { local currency) }\end{array}$ & 311 & 0.395 & 5.43 & -30 & 16 \\
\hline $\begin{array}{l}\text { Constant price GDP per capita (Summer- } \\
\text { Heston) }\end{array}$ & 328 & 1171.48 & 527.363 & 326.49 & 3003.08 \\
\hline Annual population growth & 336 & 2.63 & 0.74 & 0.01 & 4.67 \\
\hline investment rate (GDN Data) & 219 & 17.40 & 6.75 & 5.96 & 48.4 \\
\hline Brain drain Côte d'Ivoire (no schooling) & 183 & 0.0289 & 0.03296 & 0.00039 & 0.1317 \\
\hline Brain drain Côte d'Ivoire (primary) & 225 & 0.028 & 0.035 & 0 & 0.16 \\
\hline Brain drain Côte d'Ivoire (secondary) & 187 & 0.039 & 0.096 & 0 & 0.908 \\
\hline Brain drain Côte d'Ivoire (tertiary) & 220 & 0.195 & 0.397 & 0 & 2.017 \\
\hline Brain drain France (tertiary-students) & 64 & 0.0235 & 0.0123 & 0.0052 & 0.05 \\
\hline Brain drain France (tertiary) & 264 & 0.083 & 0.33 & 0.005 & 4.94 \\
\hline Brain drain France (primary) & 280 & 0.0023 & 0.004 & 0.00015 & 0.0426 \\
\hline Brain drain France (secondary) & 209 & 0.017 & 0.029 & 0.0011 & 0.25 \\
\hline domestic population above 15 & 336 & $2,893,556$ & $1,761,602$ & 327,982 & $9,533,807$ \\
\hline $\begin{array}{l}\text { Logarithmic total remittances flows per } \\
\text { capita }\end{array}$ & 168 & 2.425086 & 0.901 & 0.393 & 3.84 \\
\hline Remittances (Millions of US\$) & 168 & 56.54 & 47.50 & 1 & 192 \\
\hline
\end{tabular}




\section{A2 Tests for regression 3 in table 4}

\section{Test 1: Fixed Effects or Random Effects? A Hausman (1978) Test Approach}

Hausman (1978) suggested a test to check whether the individual effects $\left(A_{i 0}\right)$ are correlated with the regressors $\left(X_{i t}\right)$. In case of correlation (see Assumption 3, Arcand and d'Hombres 2002), fixed effects model should be applied.

- Under the Null Hypothesis: Orthogonality, i.e., no correlation between individual effects and explanatory variables. Both random effects and fixed effects estimators are consistent, but the random effects estimator is efficient, while fixed effects are not.

- Under the Alternative Hypothesis: Individual effects are correlated with the X's. In this case, random effects estimator is inconsistent, while fixed effects estimator is consistent and efficient.

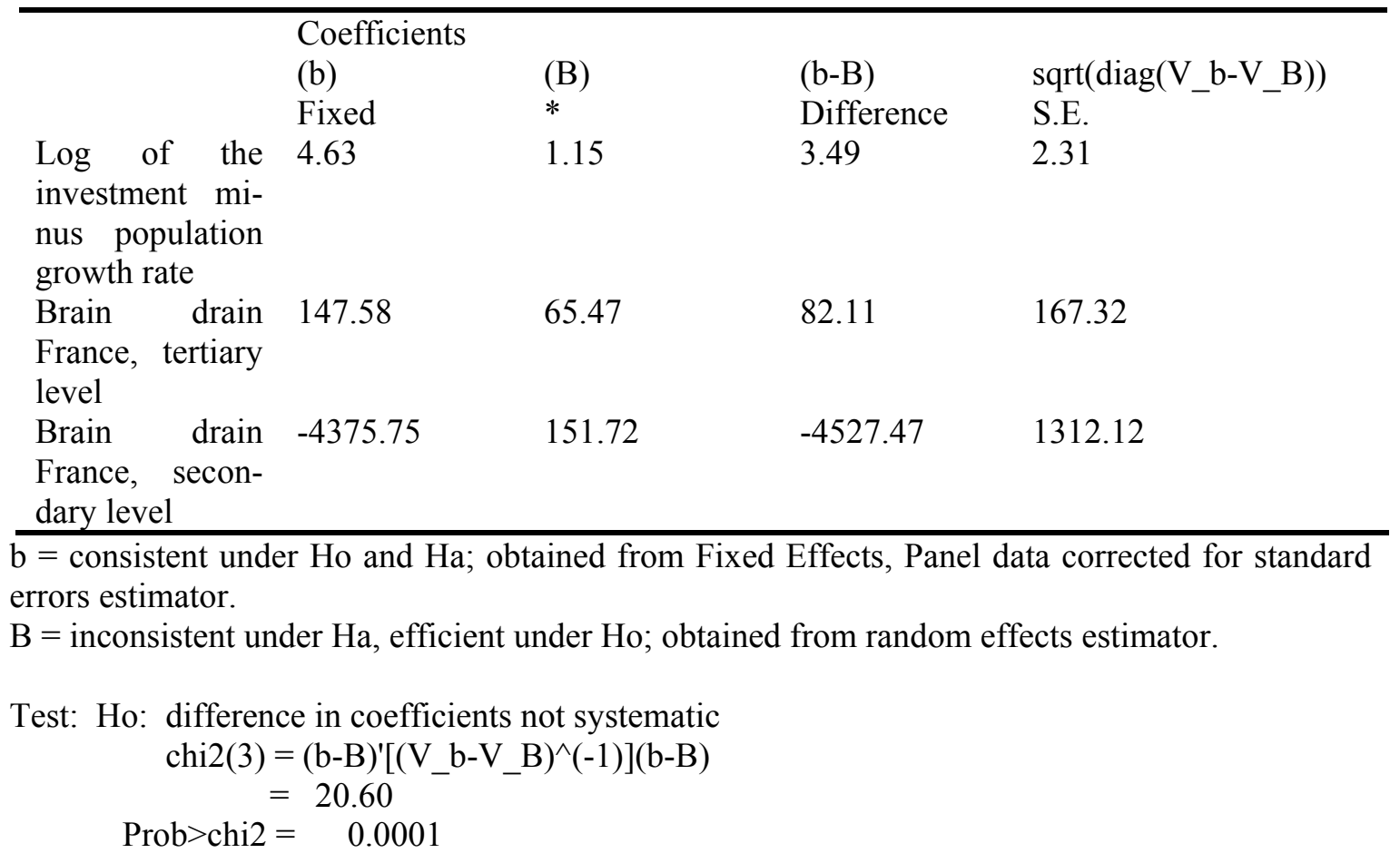

Based on the preceding test, it can seen that the tests statistic (20.60) is greater than the critical value of a Chi-squared (3df, $5 \%$ ) $=7.815$.

Therefore, the null hypothesis can be rejected. Given such result, the preferred model is the fixed effects. 
However it should be noted that the assumption that one of the estimators is efficient (i.e., has minimal asymptotic variance) is a demanding one. It is violated, for instance, if the model is somehow misspecified or in case of "small sample" problem.

\section{Test 2: Is the difference in the countries specific-effects statistically significant?}

I re-estimate here the fixed effects estimators in regression 3, table 4 including the intercept and the dummies except one that is seen as the benchmark (Burkina Faso dummy). Based on a F-test, I compare the R-square from the unrestricted fixed effects with dummies and the restricted Pooled OLS.

$\mathrm{F}(\mathrm{n}-1, \mathrm{nT}-\mathrm{n}-\mathrm{K})=[(\mathrm{Ru} 2-\mathrm{Rp} 2) /(\mathrm{n}-1)] /[(1-\mathrm{Ru} 2) /(\mathrm{nT}-\mathrm{n}-\mathrm{k})]$, where the subscript " $u$ " refers to the unrestricted regression (fixed effects with dummies), and the subscript "p" to the restricted regression (POLS). Under the null hypothesis, POLS are more efficient.

The calculated-F $=3.499031$ is compared to the critical value of $F(5,62-6-14)=F(5$, 42) $=2.438$ at $5 \%$ level. Therefore, the null hypothesis of common intercept for all WAEMU countries is rejected.

It appears that only Niger's growth performance is significantly smaller than the performance of Burkina Faso. 


\section{Test 3: Orthogonality tests for Regression 3, Table 4:}

Table A2-1: Nakamura and Nakamura's endogeneity tests

\begin{tabular}{ll}
\hline & Annual per capita GDP growth (constant \\
& local currency) \\
\hline Log of the investment minus population growth rate & 7.425 \\
& $(2.78)^{* * *}$ \\
Brain drain France, tertiary level & 210.806 \\
& $(2.34)^{* *}$ \\
Brain drain France, secondary level & 207.248 \\
& $(1.78)^{*}$ \\
Initial GDP per capita & -0.039 \\
& $(-3.63)^{* * *}$ \\
Brain drain Cote d'Ivoire, no schooling level & -144.794 \\
& $(-2.92)^{* * *}$ \\
Brain drain Cote d'Ivoire, secondary level & -199.266 \\
& $(-3.52)^{* * *}$ \\
Brain drain Cote d'Ivoire, tertiary level & 8.673 \\
& $(0.95)$ \\
Residuals, Initial GDP per capita & 0.013 \\
& $(0.68)$ \\
Residuals brain drain Cote d'Ivoire, no-schooling & -183.037 \\
level & \\
Residuals brain drain Cote d'Ivoire, secondary level & $(-0.43)$ \\
& 52.934 \\
Residuals brain drain Cote d'Ivoire, tertiary level & $(0.46)$ \\
Constant & -113.594 \\
Observations & $(-2.28)^{* *}$ \\
R-squared & 26.407 \\
\hline Z & $(3.05)^{* * *}$ \\
& 55 \\
& 0.42 \\
\hline
\end{tabular}

$\mathrm{Z}$ statistics in parentheses

* Significant at $10 \% ; * *$ significant at $5 \% ; * * *$ significant at $1 \%$

Wald tests of the brain drain residuals:

(1) Residuals brain drain Cote d'Ivoire, no-schooling level $=0$

(2) Residuals brain drain Cote d'Ivoire, secondary level $=0$

(3) Residuals brain drain Cote d'Ivoire, tertiary level $=0$

$\mathrm{F}(3,43)=2.43$

Prob $>F=0.0781$

The null of the orthogonality assumption that the residuals of all the auxiliary regressions are zero at 5 percent cannot be accepted. 


\section{A3 Analysis of correlation and variability for final regression 3 in table 4}

Table A3-1: Correlation among model covariates

\begin{tabular}{|c|c|c|c|c|c|c|c|}
\hline & (1) & (2) & (3) & (4) & (5) & (6) & (7) \\
\hline $\begin{array}{l}\text { Log of the investment ratio minus } \\
\text { the population growth rate (1) }\end{array}$ & 1.00 & & & & & & \\
\hline $\begin{array}{l}\text { Constant price initial GDP per } \\
\text { capita Summer Heston (2) }\end{array}$ & -0.26 & 1.00 & & & & & \\
\hline $\begin{array}{l}\text { Brain drain Côte d'Ivoire (no } \\
\text { schooling level) (3) }\end{array}$ & 0.59 & -0.65 & 1.00 & & & & \\
\hline $\begin{array}{l}\text { Brain drain Côte d'Ivoire } \\
\text { (secondary schooling) (4) }\end{array}$ & 0.42 & -0.62 & 0.48 & 1.00 & & & \\
\hline $\begin{array}{l}\text { Brain drain Côte d'Ivoire (higher } \\
\text { schooling) (5) }\end{array}$ & 0.57 & -0.59 & 0.73 & 0.67 & 1.00 & & \\
\hline $\begin{array}{l}\text { Brain drain France (higher } \\
\text { schooling) (6) }\end{array}$ & 0.47 & 0.22 & 0.15 & 0.21 & 0.15 & 1.00 & \\
\hline $\begin{array}{l}\text { Brain drain France (secondary } \\
\text { schooling) (7) }\end{array}$ & 0.31 & 0.15 & 0.16 & 0.47 & 0.27 & 0.41 & 1.00 \\
\hline
\end{tabular}

(1), (2), (3), (4), (5), (6) and (7) have the respective labels of variables in row.

Table A3-2: Variability of the endogenous variables

\begin{tabular}{|c|c|c|c|c|c|c|}
\hline Variable & & Mean & Std. Dev. & Min & Max & Observations \\
\hline \multirow{3}{*}{$\begin{array}{l}\text { Constant price initial } \\
\text { GDP per capita Summer } \\
\text { Heston }\end{array}$} & overall & 1171.48 & 527.36 & 326.49 & 3003.08 & $\mathrm{~N}=$ \\
\hline & between & & 522.82 & 551.65 & 2221.45 & $\mathrm{n}=$ \\
\hline & within & & 195.47 & 547.68 & 1953.11 & $\mathrm{~T}=$ \\
\hline \multirow{3}{*}{$\begin{array}{l}\text { Brain drain Côte d'Ivoire } \\
\text { (no schooling level) }\end{array}$} & overall & 0.029 & 0.033 & 0.00039 & 0.13 & $\mathrm{~N}=183$ \\
\hline & between & & 0.03 & 0.0054 & 0.07 & $\mathrm{n}=$ \\
\hline & within & & 0.02 & -0.041 & 0.12 & $\mathrm{~T}-\mathrm{bar}=36.6$ \\
\hline \multirow{3}{*}{$\begin{array}{l}\text { Brain drain Côte d'Ivoire } \\
\text { (secondary schooling) }\end{array}$} & overall & 0.04 & 0.096 & 0 & 0.91 & $\mathrm{~N}=187$ \\
\hline & between & & 0.080 & 0.004 & 0.199 & $\mathrm{n}=$ \\
\hline & within & & 0.082 & -0.075 & 0.825 & $\mathrm{~T}-\mathrm{bar}=31.17$ \\
\hline \multirow{3}{*}{$\begin{array}{l}\text { Brain drain Côte d'Ivoire } \\
\text { (higher schooling) }\end{array}$} & overall & 0.195 & 0.40 & 0 & 2.02 & $\mathrm{~N}=220$ \\
\hline & between & & 0.288 & 0.005 & 0.74 & $\mathrm{n}=$ \\
\hline & within & & 0.285 & -0.549 & 1.47 & $\mathrm{~T}-\mathrm{bar}=36.67$ \\
\hline
\end{tabular}


A4 Overidentification Tests (regression 3 Table 4)

A4-1 List of all instruments:

\section{List of instrumented variables:}

Initial GDP per capita

Brain drain Côte d'Ivoire (no schooling)

Brain drain Côte d'Ivoire (secondary)

Brain drain Côte d'Ivoire (tertiary)

\section{List of instruments:}

1) Twice lagged, within transformed and averaged by panel Right Hand Side variables (RHD): Initial GDP per capita, Brain drain Côte d'Ivoire (no schooling), Brain drain Côte d'Ivoire (secondary), Brain drain Côte d'Ivoire (tertiary)

\section{2) Twice lagged, external instruments}

Local human capital (no schooling)

Local human capital (primary)

Local human capital (tertiary)

Migrants-Côte d'Ivoire human capital (no schooling)

Migrants-Côte d'Ivoire human capital (primary)

Migrants-Côte d'Ivoire human capital (secondary)

Migrants-Côte d'Ivoire human capital (tertiary)

Migrants-France human capital (tertiary)

Migrants-France human capital (secondary)

Migrants-France human capital (primary)

\section{3) Exogenous regressors}

Log of the investment minus population growth rate

Brain drain France, tertiary level

Brain drain France, secondary level 


\section{$\underline{\text { A4-2 First stage tests }}$}

Table A4-1: Summary results for first-stage regressions:

\begin{tabular}{lllll}
\hline Variable & Shea Partial R2 & Partial R2 & $\mathrm{F}(13,38)$ & P-value \\
\hline Initial GDP per capita & 0.57 & 0.97 & 83.05 & 0.00 \\
Brain drain Côte d'Ivoire (no schooling) & 0.73 & 0.99 & 698.61 & 0.00 \\
Brain drain Côte d'Ivoire (secondary) & 0.57 & 0.93 & 38.41 & 0.00 \\
Brain drain Côte d'Ivoire (tertiary & 0.92 & 0.98 & 200.66 & 0.00 \\
\hline
\end{tabular}

\section{Notes for Table A4-1 of first stage regressions:}

Shea Partial R2: Shea's (1997) "partial R-squared" is a measure of instruments relevance that takes intercorrelations among instruments into account

Partial R2: more common form of "partial R-squared" (a.k.a. the "squared partial correlation" between the excluded instruments and the endogenous regressor in question) F $(13,38)$ : F-test of the excluded instruments that corresponds to the partial R-squared measure. This first-stage F-test is used as a diagnostic.

Shea Partial R2 and common Partial R2: The two measures of "partial R-squared" coincide when the model has only one endogenous regressor.

Test of external instruments for the four first stage regressions: "Local human capital (no schooling), Local human capital (primary), Local human capital (tertiary), MigrantsCôte d'Ivoire human capital (no schooling), Migrants-Côte d'Ivoire human capital (primary), Migrants-Côte d'Ivoire human capital (secondary), Migrants-Côte d'Ivoire human capital (tertiary), Migrants-France human capital (tertiary), Migrants-France human capital (secondary), Migrants-France human capital (primary)" $=\mathbf{0}$ :

$83.05 ; 698.61 ; 38.41 ; 200.66$

Prob > F: 0.00; 0.00; 0.00; 0.00

Partial R-squared of excluded instruments: $0.97 ; 0.9958 ; 0.93 ; 0.99$

\section{A4-3 Overidentification test for all instruments:}

Hansen J statistic (overidentification test of all instruments): 12.843

$$
\text { Chi-sq(9) P-val }=0.16984
$$

